\title{
Chemistry Education and Diversification of Nigerian Economy: A Remedy to National Youth Unemployment
}

\author{
Babale Abdullahi, Aisha Yusuf Lawal, Abdulazeez Isah \\ Chemistry Department, Federal College of Education, Zaria, Nigeria \\ Email address: \\ abdullahibabale12@gmail.com(B. Abdullahi), aishayusuflawal@gmail.com(A. Y. Lawal), abdulazeezisah1974@gmail.com(A. Isah) \\ To cite this article: \\ Babale Abdullahi, Aisha Yusuf Lawal, Abdulazeez Isah. Chemistry Education and Diversification of Nigerian Economy: A Remedy to \\ National Youth Unemployment. Teacher Education and Curriculum Studies. Vol. 5, No. 3, 2020, pp. 103-107. \\ doi: $10.11648 /$ j.tecs.20200503.18
}

Received: March 4, 2020; Accepted: July 16, 2020; Published: July 30, 2020

\begin{abstract}
The issue of graduate unemployment in Nigeria has become a national concern as the unemployed youths become restless. This situation has not only posed a great challenge to the economy but also retarded the economic growth of the country. The reality is that the government and the organized private sectors cannot absorb the graduates of these institutions The graduate unemployment problem has generated several other socio-economic problems in the country manifesting in the following: militancy in the Niger Delta, political thuggery among youths, increased rate of armed robbery, kidnapping and Boko Haram. Nigeria is a mono-economy nation; the economy depends mainly on crude oil. The fluctuating oil price seriously affects the Nigerian economy. The government which has been the highest employer of labor cannot offer jobs to unemployed youths. A possible solution to this problem is for the Nigerian government to diversify its national economy. Diversification presents the most competitive and strategic option for Nigeria in light of her developmental challenges and given her background. The importance of creativity and innovation through teaching chemistry entrepreneurship skills has been recognized as a panacea for unemployment among youth. Nigeria's innovative capacity and the development of a creative and knowledge-intensive economy and society can be achieved through reinforcing the role and training of graduates in the knowledge of entrepreneur skills and focusing course curricula on creativity, innovation, and entrepreneurship. It is hereby recommended that emphasis should be laid on chemistry entrepreneurial skills and functional educational technology such as design, production, and modernization of indigenous resources among students through practices and innovations for achieving self-reliant generate.
\end{abstract}

Keywords: Graduate, Unemployment, Diversification, Innovation, Entrepreneur

\section{Introduction}

Every year, Nigerian tertiary institutions pass out more than five hundred thousand students, and after the mandatory National Youth service; the students go into the labor market in search of Jobs. A study found that graduate turnout outpaced the graduate employment rate every year. Enrolment in tertiary institutions in Nigeria is increasing annually. The reality is that the government and the organized private sectors cannot absorb the graduates of these institutions. The issue of graduate unemployment in Nigeria has become a national concern as the unemployed tend to be anxious, restless, and depressed. The situation of unemployment in Nigeria is indeed alarming [1], [2]. This situation has not only posed a great challenge to the economy but also retarded the economic growth of the country. The
National Bureau of Statistics put the unemployment rate in the first quarters of 2013 at $23.9 \%$ [3]. Despite steady growth in Gross Domestic Product (GDP) in Nigeria over the past years, unemployment has been on the increase. The World Bank stated in its study of "employment and growth in Nigeria", that although an impressive GDP growth rate of $7 \%$ per annum has been achieved since 2001, there is a general perception that the high growth rate has not translated into commensurate employment in the country, just as it said the absence of credible database on employment on sectoral and national basis remains a problem [4]. The recent report by the World Bank that about 40 million Nigerians are unemployed is disturbing; the global financial institution has classified Nigeria among nations prone to widening poverty and socioeconomic crisis arising from effects of the global economic melt-down [5]. The graduate unemployment problem has 
generated several other socio-economic problems in the country manifesting in the following: militancy in the Niger Delta, political thuggery among youths, increased rate of armed robbery and kidnapping, and Boko Haram [6]. Nigeria is a mono-economy nation, the economy depends mainly on crude oil. The fluctuating oil price seriously affects the Nigerian economy. The government which has been the highest employer of labor cannot offer jobs to unemployed youths. A possible solution to this problem is for the Nigerian government to diversify its national economy. Diversification involves shifting away from the monotony dependence to the creation of many sources of income and livelihood. Chemistry Education through the utilization of chemical entrepreneurship will boost the diversification of the Nigerian economy. Chemistry as a tool for every facet of livelihood, through the chemistry entrepreneurship, is a panacea to the endemic problem of youth unemployment. The Nigerian government must take a proactive step, do the right and take the appropriate deliberate option of fixing the nation, we are not going anywhere and the number of unemployed graduates/ youths will continue to increase yearly and social disorderliness will continually be the order of the day.

\section{Diversification of Nigerian Economy}

Nigeria is the largest oil exporting country in Africa and has a rapidly growing economy. The country follows a resource-based growth strategy driven by the production and exporting of oil. With the volatility of global oil prices and the often volatile growth of Nigeria's economy, the country has wasted much of its opportunities to break away from underdevelopment despite its massive natural and human resources endowments. It has dwelled only on its huge crude oil resources as the major source of revenue, driving a monolithic economy for years despite the enormous developmental challenges it faces. Regrettably, the oil resources are being mismanaged and a substantial part of it has gone on rent-seeking and red-tapism common in Nigerian bureaucracy. For more than a decade now, Nigeria has been enjoying high levels of economic growth, human development, and relative political stability. As it continues along the path of economic progress, the country must find ways to diversify its economy by boosting non-traditional sectors, expanding its range of products for exports, and engaging new economic and trade partners. As a matter of priority, the Nigerian government must encourage the diversification of Nigeria's economy. It is the only viable way to survive the current environment of global economic uncertainty with the volatility of oil prices. The government mustn't believe that oil provides an endless source of revenue

At the advent of democracy in 1999, Obasanjo's first full national budget in 2000 was under N600bn naira but now we have as much as $800 \%$ increase over this, yet we can only see little development but the surplus of preaching and governance by billboards while vision 20-2020 is in a state of rest like Newton's first law of thermodynamics. We say unequivocally that resource looting and wastage is much concentrated at the state levels because most of our Governors are not just most wanting but problematic and the very impediment to development.

Diversification presents the most competitive and strategic option for Nigeria in light of her developmental challenges and given her background. Diversification has a lot of benefits for Nigeria to maximally utilize her abundant resource - base to rebuild the economy and enjoy the benefits of all the linkages, synergy, economies of scale, grow national technology and foreign investment profile, build human capital, exploit new opportunities, lessen averagely operational costs, increase national competitiveness and grow the standard of living and confidence of the citizens for a national renaissance.

Diversification does not occur in a vacuum. And, the need to have in place an enabling environment to make diversification possible remains necessary. Several key drivers have already been identified. These, for example, include investment, entrepreneurship, trade, industrial policies, a dynamic growth performance, macroeconomic stability, a competitive exchange rate, and expansionary but responsible fiscal policy as well as institutional variables such as good governance and absence of conflict and corruption.

\section{The Relevance of Chemistry Education in Society}

Chemistry is that aspect of science that deals with the nature of matter, its properties, and its change in condition. It is very important to human life and is very essential for human survival. It is the core of every technology we enjoy today. The power of chemical science is what creates an enabling infrastructure that delivers food, medicine, and materials that are the hallmarks of modern life. Its importance in modern societies is indisputably significant because of its requirements as a pre-requisite to the study of courses like medicine, pharmacy, and all fields of engineering. Many publications emphasize the relevance of science education (and chemistry education in particular) to maintain the economic wealth of modern societies, thereby justifying science skills among the young generation as essential for continued prosperity in our future.[7] For the majority of students, Chemistry is just a classroom affair. Rarely do students know that chemistry application is found on the farm, at home, and play.

Chemistry Education has a crucial role to play in helping to find answers to various human and socio-economic problems as well as making society more scientifically literate. The inability of the chemistry teacher to cite and expose the economic relevance of chemistry to students through the appropriate teaching methods has led to a poor misconception about chemistry. The commonly used lecture method has continued to hide this aspect of chemistry. Application of chemical knowledge learned in the class to utility depends on the teacher's use of appropriate teaching 
techniques that will help students understand the relevance of the concept learned to daily life. Chemistry is an investigative subject and thus is activity-oriented. Learning chemistry is something students do, not something that is done for them [8]

\section{Chemistry Entrepreneurship}

Entrepreneurship according to [9] is the effective manipulation of human intelligence as demonstrated in creative performance, choosing to assume risk, identifying business opportunities, gathering resources, initiating actions and maximizing opportunities Steinhoff and [10] opined that entrepreneurship occurs when an individual develops a new venture, a new approach to an old business or idea, a unique way of giving the market place a product or services by using resources in a new way under the condition of risk Entrepreneurship involves the ability to set up a business enterprise as different from being employed [11]. According to [11], this ability should be acquired and should differ in some respect from the abilities acquired to enable a person to obtain paid employment.[12] refers to entrepreneurship as the dynamic and complex production factor which involves the ability to recognize a business opportunity and mobilize both human and material resources to exploit the identified opportunity. Entrepreneurship is defined by [13] as a clear manifestation of effective manipulation of human intelligence as demonstrated in creative resources in a new way in the course of creating a new business concept or opportunity within an existing firm. According to [14], entrepreneurship is the process of creating something new with value, by devoting quality the necessary time and effort, assuming the accompanying financial, psychic, and social risks, and receiving the resulting rewards of monetary and personal satisfaction and independence.

Entrepreneurship Education according to [15] refers to a carefully planned process leading to the acquisition of entrepreneurship skills for efficient and effective living. Entrepreneurship Education is the key that opens the way to economic growth and. Chemistry entrepreneurship according to [16] involves the process of converting innovations on Chemistry into marketable products for commercial gain. With increasing awareness in Chemistry entrepreneurship, there is a paradigm shift from conducting basic research whose results end up only in academic journals to patenting and commercializing them for economic gains.

\section{Chemistry Entrepreneurship Skills}

To be able to produce job creators, there is the need to infuse the spirit of entrepreneurship into the mode of instruction of science teachers which will facilitate the emergence of entrepreneurial chemistry students. [17] clearly stated that the introduction of entrepreneurship education into our science curriculum could lead to a continuous and sustainable technological growth of the country. The acquisition of professional qualification in chemistry, equip an individual with skills to be self-employed because of having acquired entrepreneurial and/or process skills. Functional chemistry education emphasizes the applicability or transferability of the acquired knowledge to the immediate environment. This is the purpose of Chemistry education as stated in the National Policy on Education [18] which includes the "Acquisition of appropriate skills and development of mental, physical and social abilities and competencies to contribute to the development of his society"(p. 67). Consequently, Chemistry, like entrepreneurship, aims to equip an individual to be selfreliant. The entrepreneurial skills will help chemistry graduates (at both secondary and tertiary school level) to become self-employed if they fail to read further or get a job. Teachers are therefore expected to expose their students to entrepreneurial skills through chemistry education to promote chemistry entrepreneurship.

Entrepreneurship skills occur when an individual develops a new venture, a new approach to an old business, or an idea or a unique way of giving the market a product or service by using resources in a new way under conditions of risk (Umar, 2006). Entrepreneurship skills help to create wealth, selfdirection, and a satisfying career and; also add value to society's well-being. Chemistry, on the other hand, is concerned with the utilization of natural substances and the creation of artificial ones. It is an artistic enterprise which offers a lot of occupational opportunities in areas like Manufacturing of goods (such as pharmaceuticals, foodstuffs, packaging, detergents, soap, flavours, fragrances, pulp and paper, paints, candles, metals, textiles, agricultural products, oxygen, chlorine, ammonia, sulphuric acid, etc.); Sales of goods; Researching; Laboratory services; Consumer education; Analytical and Consultancy services

The acquisition of professional qualification in chemistry, equip an individual with skills to be self-employed because of having acquired entrepreneurial and/or process skills. Functional chemistry education emphasizes the applicability or transferability of the acquired knowledge to the immediate environment. This is the purpose of Chemistry education as stated in the National Policy on Education [18] which includes the "Acquisition of appropriate skills and development of mental, physical and social abilities and competencies to contribute to the development of his society"(p. 67). Consequently, Chemistry, like entrepreneurship, aims to equip an individual to be selfreliant. The entrepreneurial skills will help chemistry graduates (at both secondary and tertiary school level) to become self-employed if they fail to read further or get a job. Teachers are therefore expected to expose their students to entrepreneurial skills through chemistry education to promote chemistry entrepreneurship.

Also in the area of environmental chemistry, entrepreneurial skills can be developed where the students have opportunities of being entrepreneurs. They can set up waste management services (business) which will involve the collection and disposal of waste from homes, offices, etc. This will be a worthwhile venture as [19] pointed out that the operation of 
the public health authorities responsible for the collection of waste from the government-owned and personal dustbins to the dumping sites is generally low and inadequate with the result that they remain uncollected for months. The graduates can convert waste into wealth. This will involve identifying where the waste can be taken to. A fee can be collected from the respective beneficiaries (homes, offices, market, etc) who may be charged based on the amount of waste they throw away i.e. they may be charged by volume and weight of their garbage. Besides, the waste could be sorted and some of the materials recycled for economic benefits.

\section{Chemistry Entrepreneurship Skills and Self-reliance}

The acquisition of Chemistry entrepreneurship skills is a solution to the frightening unemployment Growth. The skills when acquired lead to one becoming self-reliant. Chemistry has cut across almost all fields of human endeavors and could, therefore, be utilized to meet the needs and aspirations of the teeming unemployed graduates in the area of job creation since there are abundant opportunities which include the following;

1. Enhancement of increasing food production through sourcing for composts manure, production of fertilizer from local raw materials.

2. Insecticides and pesticide production from local raw materials like neem tree seeds, sweet pepper, and other plant materials used in grain storage, etc.

Chemistry entrepreneurship skills education is a carefully planned process leading to the acquisition of entrepreneurial skills for effective living. Entrepreneurship skills education is an instrument that empowers the youths to be in control of their future, have more opportunities to exercise creative freedom, higher self-esteem, and an overall greater sense of control over their own lives. This implies that entrepreneurship is a major source of job creation and innovation and it is largely for this reason that it has been equated with new venture creation and small business development.

\section{Conclusion}

The importance of creativity and innovation through teaching chemistry entrepreneurship skills has been recognized as a panacea for unemployment among youth. Nigeria's innovative capacity and the development of a creative and knowledge-intensive economy and society can be achieved through reinforcing the role and training of graduates in the knowledge of entrepreneur skills and focusing course curricula on creativity, innovation, and entrepreneurship.

\section{Recommendations}

1. It is hereby recommended that emphasis should be laid on entrepreneurial skills and functional educational technology such as design, production, and modernization of indigenous resources among students through practices and innovations for achieving selfreliant generation.

2. The federal government should establish a sustainable national exhibition for educational technology students to stimulate the production of high-quality audio-visual materials.

3. The government both at the federal and state level should encourage and support multi-disciplinary research in educational technology, promote regional and international cooperation and collaboration in form of conferences, seminars, and symposium specifically targeted towards achieving the goals of building selfreliant generation.

4. Curriculum developers should integrate entrepreneurial aspects at all levels of educational technology curriculum and training by promoting learning by discovery method, experiential learning, participatory approach, and through interactive environments, promoting attitudes receptive to self-reliance among all education technology students.

5. Educational technology instructors should introduce an intensive mentoring program by building alliances and relationships with other entrepreneurs, business professionals, alumni, and investors so that students can build professional passion, gain personal insights, develop concepts, and formulate new ideas with this form of training

\section{References}

[1] Ogunsola, T. (2009). Lessons from Boko Haram Sectarian Crisis. The Nigerian Education Times, P. 26.

[2] Aja-Okorie, U., and Adali, O. (2013). Achieving Youth empowerment through repositioning entrepreneurial education in Nigerian universities: Problems and prospects, European Scientific Journal, 9 (28), 113-132.

[3] Odia, J. O., \& Odia, A. A. (2013). Developing entrepreneurial skills and transforming challenges into opportunities in Nigeria. Journal of Educational and Social Research, 3 (3), 289.

[4] Abdallhamid Y 2009. Nigeria: Unemployment Worries World Bank. World Bank Report.

[5] World Bank 2014. Alleviating Unemployment and Poverty Under Adjustment. Reports of an ILO/JASPA Employment Advisory Mission. Addis Ababa

[6] Ibe, E. O. (2012) Re-engineering entrepreneurial education for employment and self productivity in Nigeria. Knowledge Review, 26 (1), 1-6.

[7] Vermaak, I., \& Bradley, J. D. (2003). New technologies for effective science education break the cost barrier.

[8] National Research Centre (NRC, 1996). National Science Education Standards. Washington D. C. National AcademyPress 
[9] Ikeme J. U. and Onu, P. O. (2006). Practical Tips to Successful Entrepreneurship Education and wealth creation strategies: Practical tips for economic empowerment and survival. Great AT Express Publishers Nsukka, p. 55.

[10] Steinhoff, D and burgress, FF (1993) Small business management fundamentals $6^{\text {th }}$ edition New York Mcgraw hill inc $\mathrm{p} 110$.

[11] Nwaokolo, P. O. (2004). Entrepreneurial Initiatives in colleges of Education Programmes. Paper presented at Education Tax fund (ETF) workshop on capacity building at F.C.E (T) Umunze.

[12] Odo, G. E. (2001). Accentuating Entrepreneurial Skills as a Basis for Poverty Reduction in Nigeria. Proceedings of the $14^{\text {th }}$ Annual Conference of Nigerian Association of Teachers of Technology NATT, p. 60-63.

[13] Uzoka, F. A. (2005). Home Economics as a tool for entrepreneurship education in the $21^{\text {st }}$ Century. Knowledge Review, 11 (6) 83.

[14] Aminu, A. A. (2008). Entrepreneurial development in Nigeria: A reading manual; Development of management, Federal University of Technology, Yola.
[15] Lemechi S. N. and Anyakoha E. U (2002). Teaching Entrepreneurship in Vocational Education. An imperative Towards Sustainable Educational development in Nigeria: Nigerian Journal of curriculum studies 9 (1) 95-99.

[16] Oyeku, O. M.; Oduyoye, O. O.; Elemo, G. N.; Akindoju, A. F.; Karimu, F. A. \& Unuigbe, K. O. (2015). Chemistry entrepreneurship for small and medium enterprises development: A panacea for job and wealth creation. Industrial Engineering Letters, 5 (4) 1-2.

[17] Ogunleye, A. O. (2007). Building a sustainable science curriculum in Nigeria: Accommodating local adaptation, levering technology and enhancing areas of improvement for quality assurance. STAN Proceedings of the $50^{\text {th }}$ Anniversary Conference 36-44.

[18] Federal Government of Nigeria (2004). National policy on education Lagos. Federal ministry of Education.

[19] Umar, J. W. (2006) Effective integration of entrepreneurial education for quality assurance in Home Economics education. Nigeria Academic Forum. 10 (2). P. 86. 